\title{
THE ROLE OF SPIRITUALITY IN THE BEHAVIOR OF SHARIA BANK MOBILE BANKING: EVIDENCE FROM INDONESIA
}

\author{
NUR INAYAH ${ }^{1}$, RATNO AGRIYANTO ${ }^{2}$, WARNO ${ }^{3}$ \\ Universitas Islam Negeri Walisongo Semarang
}

\section{Abstract}

The purpose of this research is to examine the behavior of sharia bank customers in using mobile banking (using a modified Technology Acceptance Model) with additional spiritual variables. The research population is about one hundred customers of sharia bank in Indonesia. The results of this study indicate that: (1) perceived ease has a positive effect on the attitude of using mobile banking through the use of perceptions, (2) the perception of benefits has a positive effect on the attitude of using mobile banking, (3) expediency has a positive effect on the behavioral interest in using mobile banking, (4) behavioral interest has a positive effect on mobile banking use, and (5) spiritual motivation has a positive effect on mobile banking use.

Tujuan dari penelitian ini adalah untuk menguji perilaku pelanggan bank syariah dalam menggunakan mobile banking (menggunakan Technology Acceptance Model yang dimodifikasi) dengan variabel spiritual tambahan. Populasi penelitian adalah seratus nasabah bank syariah di Indonesia. Hasil penelitian ini menunjukkan bahwa; (1) persepsi kemudahan berpengaruh positif terhadap sikap menggunakan mobile banking, (2) persepsi manfaat memiliki pengaruh positif terhadap sikap menggunakan mobile banking, (3) kemanfaatan memiliki efek positif pada minat perilaku dalam

Corresponding author; email: ${ }^{1}$ inayahnur439@gmail.com, ${ }^{2}$ ratnoagriyanto@walisongo.ac.id, ${ }^{3}$ warno@walisongo.ac.id 
menggunakan mobile banking, (4) minat perilaku memiliki efek positif pada penggunaan mobile banking, dan (5) motivasi spiritual memiliki efek positif pada penggunaan mobile banking.

Keywords: Islamic bank; mobile banking; spirituality; Technology Acceptance Model.

\section{Introduction}

Spirituality has been linked to working sector, business, leadership, and religion. The Western countries which are known for their secularism link many elements of spirituality to various aspects of life. Spirituality has an important influence on a person's psychological work. Some researches show that the level of employees' religiosity influences their attitudes and work behavior. The work attitude includes organizational commitment and job satisfaction which then has a direct impact on work productivity. According to a research conducted by Hijri, for business people, the values of Islamic spirituality are very potential to be used to produce attitudes and characters that can be implemented to achieve business continuity that is in accordance with the Islamic perspective. The research conducted by Shofwa also shows that spiritual motivation influences the religious performance of the employees and the lecturers of STAIN Purwokerto (Shofwa 2013). While, the research conducted by Alfani shows that Islamic spiritual motivation influences the interest in using internet banking services at Syariah Mandiri Bank of Surabaya (Alfani 2015).

The research shows that one's spiritual motivation has an important role to form human attitudes and behavior. The concept of motivation can be used to predict work attitudes, performance, and interest. Therefore, spiritual motivation can also be used to provide an explanation of the behavior of bank customers in using mobile banking. This is based on the economic 
behavior of a person who has a goal to fulfill all his needs in achieving prosperity or benefit (Rahmawaty 2012). Thus, spiritual motivation is regarded as a variable that can affect the behavior of bank customers in using mobile banking.

As one of the modern information technologies, the internet is currently developing very rapidly. Technology infrastructure in Indonesia is developing very quickly as said by Alam (2007) that the state influences the progress of information and Poon (2008) adds that adoption will be fast due to technology. Akturan and Tezcan (2012) also states especially in the economic sector, the internet can provide for the delivery of information quickly, widely and accurately. The development of internet technology has now provided many opportunities for the creation of internet-based business applications. One of the industrial sectors that takes advantage of these opportunities is the banking sector where this opportunity is used to develop service facilities. It is in line with Basias' opinion that one of the service-oriented architectures (SOA) (Basias, Themistocleous, and Morabito 2013) is mobile banking. Mobile banking service facilities have now become a concern for competition among banks to capture market share because online banking can increase customers (Singh 2004).

Mobile banking is a banking service provided by banks for their customers to be able to use banking services without limit of space and time and also based on cellular and internet technology which makes it easy to carry out various banking transactions without having to come directly to the bank because it can be accessed at any time (Sa'diyah and Aziroh 2013).

Because of the development of internet-based products, both conventional banks and Islamic banks have taken the advantage. Some Islamic banks that have participated in developing mobile banking as internet-based products are Muamalat Bank, Syariah 
Mandiri Bank (BSM), BNI Syariah, BRI Syariah, Bank Syariah Bukopin, Bank Mega Syariah, BCA Syariah and others. Mullan, Bradley, and Loane (2017) state that through product innovation with internet technology in the form of mobile banking, many benefits can be obtained such as customer convenience and strategic importance.

Based on a survey conducted by the Sharing Vision (2015), at the beginning of 2015, the growth of mobile banking users from four banks (Mandiri Bank, BCA, BNI and BRI) reached 23.65 million users in Indonesia. This number has increased by $25 \%$ from the previous year which were only 18.8 million users. However, according to the research institute, Miscrosave, the internet users for financial services in Indonesia are only $0.73 \%$ of the total cellular phone users. It is much lower than Malaysia with $5.79 \%$ and Cambodia with $2.73 \%$. This is because the number of smartphone users in Indonesia is only 20 to $40 \%$ of the total SIM card users (200 million users) and the people of Indonesia who have savings in formal financial institutions or banks are only 36\% (Tempo 2016). According to Rahayu's research, the reality is also proven that there are still many customers who prefer to do transactions manually by queuing at the bank or at the ATM. And there are still many customers who have mobile banking but are underutilized because not everyone understands how to use it and the level of ability of customers to use mobile phones and the internet is quite low (Wahyudi 2014). According to Akturan and Tezcan (2012), young people tend to prefer mobile banking.

An approach is needed to explain how the customers of sharia banks accept or reject the use of mobile banking. The model that is widely used to measure revenue using technology is the Technology Acceptance Model (TAM). This model can describe the level of individual acceptance to the application of technology and interest in a behavioral use of technology which is influ- 
enced by two main factors; perceived ease of use and perceived usefulness. Apart from these two factors, there are also several other factors like attitude toward use, interest in behavior use (actual behavior use), and actual system use.

Perceived ease of use is an individual's level of confidence or belief that the use of certain system technologies is easy, free from difficulties, and does not require hard work (Khakim 2016). Attitude toward use is a feeling of support or favorableness or a feeling of not support or unfavorableness of an object that will be addressed. This feeling arises from an individual evaluation of the belief in the results obtained from certain behaviors (Mutia 2016). Behavioral intention to use can be interpreted as a response or reaction of someone who has the desire to use technology. Someone will be satisfied using technology if they believe that the technology is easy to use and will improve their performance (Sahilatua and Noviari 2013). The actual system use is conceptualized in the form of measurement of the frequency and duration of the use of technology (Ratnaningrum 2013).

Based on the aforementioned reasons, the researcher wants to examine further whether the addition of spiritual motivation variables in the TAM model affects the behavior of using mobile banking among customers of Islamic banks. Spiritual motivation is the driving force that awakens activity in the individual, and causes behavior and directs it to a specific goal. Spiritual needs are the needs of fitr which fulfillment depends on the perfection of individual growth and maturity. So that the fulfillment of spiritual needs is very influential in the formation of self-concept that will manifest in one's behavior (Yasa 2013).

\section{Literature Review}

\section{Technology Acceptance Model}

Technology Acceptance Model (TAM) is a model adopted from the Theory of Reasoned Action (TRA) model. This theory 
is developed by Martin Fishbein and Icek Ajzen. The TRA model is a theory of reasoned action with a premise that reaction and one's perception of something will determine the attitude and behavior of that person. Furthermore, Davis developed a broader model of TAM to explain the interest in the behavior of technology use. This theory has two main factors that influence interest in the behavioral use of technology; perceived ease of use and perceived usefulness. Khakim (2016) and Minjoon (2016) state that perceived ease of use is the level of confidence or trust of individuals that the use of certain system of technology is easy, free from difficulties, and does not require hard work. While perceived usefulness is the level of confidence or individual belief that the use of certain system of technology will improve work performance (Khakim 2016). The original model of TAM that Davis introduced before being modified can be seen in figure 1 .

Figure 1

The model of Technology Acceptance Model

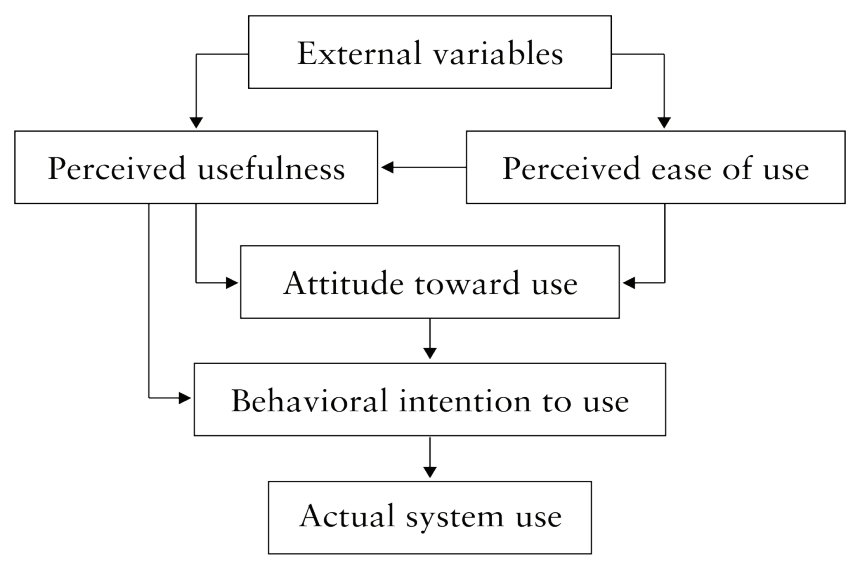

Figure 1 explains the relationship between variables contained in the Technology Acceptance Model theory, where the external variables are considered to have an effect on perceived usefulness and perceived ease of use. While perceived ease of use 
will affect perceived usefulness. Both perceptions will later influence the attitude toward use. On the other hand, perceived usefulness will affect the behavioral intention to use. Furthermore, the behavioral intention to use will be influenced by the attitude toward use and at the same time will affect the actual system use (Khakim 2016).

\section{Mobile Banking}

Mobile banking is a service provided by a bank or other financial institutions that allows its customers to conduct financial transactions remotely by using mobile devices such as smartphones or tablets. Whereas, Hanif et al., in their research stated that mobile banking is a bank's facility in the modern era that follows technology and communication developments. Services available on mobile banking include payments, transfers, history, and others. The use of mobile banking service on cellular phones allows customers to carry out their banking activities more easily and also without limit of space and time (Akhtar 2013).

Ramadhan and Herianingrum in their research state that mobile banking is a service that uses information technology. Mobile banking or shortly called as m-banking is a banking service provided by a bank to its customers to support the flow and ease of banking activities (Siradj 2017). Whereas according to Wulandari and Moeliono, mobile banking is a banking facility or service that uses communication tools such as mobile phones. Mobile banking is generally classified into 3 parts: informational, communicative, and transactional.

\section{Hypotheses}

The positive effect of the ease perception on the attitude of using mobile banking

Perceived ease of use is defined as the level at which a person believes that the use of technology is easy and does not require 
the effort of the user. This concept includes the clarity of the purpose of the use of technology and the ease of use of the system to reach the goal according to the wishes of the user. If someone believes that the system of technology is easier to use, they will use it. On the contrary, if someone think that the system of technology is not easy to use, they will not use it (Saputri 2015). Based on this explanation, it can be said that perceived ease of use is the level to which someone believes that the technology is easy to use and does not require hard work so that it is frequently used. In line with Davis' opinion, according to Bapat, banks are supposed to add various facilities to maintain and facilitate their customers (Bapat 2017). Davis provides several indicators that are used to measure perceived ease of use, including: easy to learn, controllable, clear and understandable, flexible, easy to become skillful, and easy to use. Based on the TAM theory and previous research, the first hypotheses formulated in this study are:

H1a: Ease perception has a positive effect on the attitude of using mobile banking.

H1b: Ease perception has a positive effect on the attitude of using mobile banking through the perception of benefits.

The positive effect of the benefit perception on the attitude of using mobile banking

According to Davis, perceived usefulness is defined as the level at which someone believes that the use of technology is something that can improve their work. Hosain states that customer perceptions will influence use loyalty. This concept relates to the benefits of using technology for its users (Digabriele 2009). If someone believes that technology is useful then they will use it (Khakim 2016). Davis provides several indicators that are used to measure perceived usefulness, among others: accelerating work, improving performance, increasing productivity, 
THE ROLE OF SPIRITUALITY IN THE BEHAVIOR ...

effectiveness, simplifying work, and useful (Agriyanto 2015). Based on the TAM theory and previous research, the second hypothesis formulated in this study is:

H2: Benefit perception has a positive effect on the attitude of using mobile banking.

The positive effect of the attitude of use on the interest in the behavior of using mobile banking.

According to Ajzein, attitude toward behavior is a feeling of support or favorableness or a feeling of not support or unfavorableness of an object to be addressed. This feeling arises from an individual evaluation of the belief in the results obtained from certain behaviors (Mutia 2016). Whereas according to Davis, the attitude towards the use in the TAM theory model is conceptualized as an attitude towards the use of a system in the form of acceptance or rejection as an effect of using technology in work. Furthermore, Yahyapour defines attitude as a form of evaluation of the consequences of carrying out certain behaviors (see Ratnaningrum 2013). Kwateng (2018) and Agriyanto (2016) are also in line to provide several indicators to measure attitudes towards internet banking use, among others: internet banking is fun to use, using internet banking is a good idea, internet banking is considered necessary, appealing to all banks to use internet banking, and using internet banking is wise idea. Based on the TAM theory and previous research, the third hypothesis formulated in this study is:

H3: The attitude of use has a positive effect on the interest in the behavior of using mobile banking.

\section{Benefit perception has a positive effect on the interest in the behavior of mobile banking use}

Suryobroto explains that interest is a tendency in individuals to be attracted to an object or to enjoy an object. If a person is 
interested in something then he will feel happy or interested in the object of interest. While Mappier explains that interest is a mental device consisting of feelings, hopes, education, fear or other tendencies that move individuals towards a choice. Furthermore, according to Sukardi, interest is one of the elements of personality that plays an important role in making future decisions. Interest will direct individuals to an object on the basis of pleasure or displeasure. So that interest can be known from statements of pleasure or displeasure with a particular object (Anendro 2016). According to Bohar Soeharto, behavior is the result of the teaching and learning process that occurs as a result of his interaction with the surrounding environment caused by personal experiences. So it is clear that behavior is influenced by both internal factors and environmental factors around it. Behavior is all human activities that are directly observed, or which can be observed by outsiders (Suharyat 2009; Agriyanto 2017). Furthermore, according to Kurt Lewin, behavior is a function of individual characteristics (motives, values, personality traits, etc.). Based on the TAM theory and previous research, the fourth hypothesis formulated in this study is :

H4: Benefit perception has a positive effect on the interest in the behavior of mobile banking use.

Interest in behavior has a positive effect on the use of mobile banking.

According to Liang Han Bank, facilitating mobile banking is a communication tool (Hans 2014). Davis states that the actual use of the system is a form of external psychomotor response that is measured by someone with real use. According to Wibowo, the use of the system is actually conceptualized in the form of measurement of the frequency and duration of the use of technology (Ratnaningrum 2013). Whereas Kusuma and Susilowati state that the use of online banking can be a bench- 
mark for the success of the system as measured by the frequency of use and diversity or difference of transactions takes place. Someone will be satisfied using the system if he believes that the system is easy to use and will increase productivity from the real conditions of use. So, the use of online banking can be defined as the real condition of customers using online banking which is conceptualized in the form of measuring the frequency of use and diversity of transactions carried out by the customers in using online banking. Rigopoulos and Askounis provide indicators that are used to measure the actual use of internet banking based on repeated use and more frequent use (Ratnaningrum 2013; Warno 2014). Based on the TAM theory and previous research, the fifth hypothesis formulated in this study is:

H5: Interest in behavior has a positive effect on the use of mobile banking.

Spiritual motivation has a positive effect on the use of mobile banking.

Motivation is the main key in interpreting and creating human actions. Meanwhile, in Islamic teachings, it is affirmed that the purpose of human life is to worship Allah swt. So, in Islam, this motivational role is called intention and worship. Intention is the main driver of human to act or make charity, while worship is the goal itself. As stated in the Quran (Al-An'am [6]: 162) meaning: "Say: verily my worship, my life, and my death are only for Allah, the Lord of the worlds'.

According to (Ratnaningrum 2013), there are three human motivations caused by needs that is physiological motivation (jismiyah), psychological motivation (nafsiah), and spiritual motivation (spiritual). A person is supposed to start his activity with the intention of worship and always considers the aspect of maslahah in obtaining prosperity in this world and in the hereafter. Whereas according to Najati, spiritual motivation is the 
driving force that an action is brought into realization, and causes behavior and directs it to certain goals. Spiritual needs are the needs of fitri which fulfillment depends on the perfection of individual growth and maturity. So that the fulfillment of spiritual needs is very influential in the formation of self-concept that will manifest in one's behavior (Yasa 2013; Warno 2013). Therefore, spiritual motivation is an important aspect in the behavior of using mobile banking. Based on the TAM theory and previous research, the sixth hypothesis formulated in this study is:

H6: Spiritual motivation has a positive effect on the use of mobile banking.

Figure 2

Proposed research model ${ }^{a}$

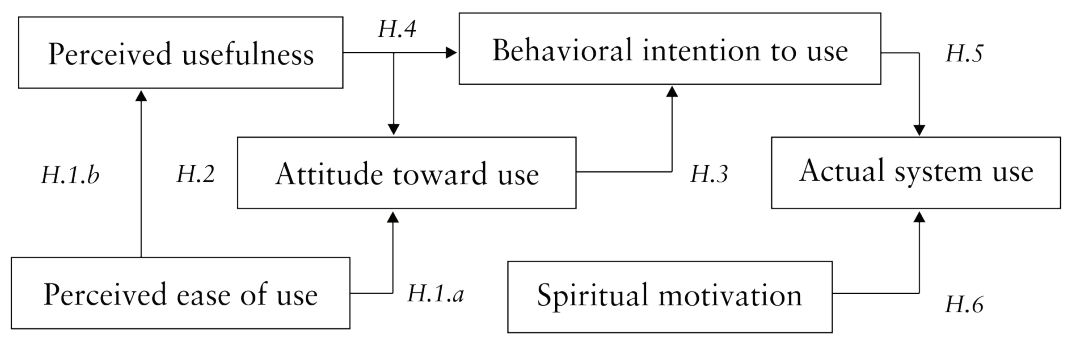

aProposed theoretical framework and hypothesis proposition

\section{Population and sample}

The population used in this study is sharia bank customers in Semarang that use mobile banking. Because the population is not known exactly, the formula used to determine the number of samples needed is the Bernoulli formula as follows:

$$
n=\frac{\left(\mathrm{Z} \frac{\alpha}{2}\right)^{2} \cdot p \cdot q}{e^{2}}
$$

Remarks:

n sample 
THE ROLE OF SPIRITUALITY IN THE BEHAVIOR ...

Z values obtained from standard normal tables with opportunities $\frac{\alpha \alpha}{22}$

e error

$\mathrm{p} \quad$ probability of population not taken as a sample

$\mathrm{q}$ probability of population taken as a sample (1-p)

This study uses a level of accuracy $(\alpha)$ of $5 \%$ and a confidence level of $95 \%$, so that the value of $Z=1.96$ is obtained. The value of the error rate (e) has been determined at $10 \%(0.1)$, the probability of the correct questionnaire $\mathrm{q}$ (received) and the wrong $\mathrm{p}$ (rejected) is 50\% (0.5) respectively. Based on the Bernoulli formula, the sample calculation that will be used by researchers is:

$$
n=\frac{(1,96)^{2} \cdot 0,5 \cdot 0,5}{(0,1)^{2}}=96,04
$$

From these calculations, the number of samples is 96.04 which is almost 100 . So the number of samples that will be used to represent the population in this study are 100 respondents. While the sampling technique used in this study is purposive sampling technique, that is the technique of determining the sample based on certain considerations. So, the selected samples are the respondents who have certain characteristics and ignore those who do not have these characteristics. The main criteria for selecting samples in this study are sharia bank customers that use mobile banking. Data collection for this study is obtained from questionnaire.

\section{Data Analysis Technique}

In this study, the data analysis technique used was statistical data on Structural Equation Modeling (SEM) using warpPLS 5.0 statistical software. SEM is an analysis that combines a factor analysis approach, a structural model, and path analysis. The method of testing the data is conducted by testing the model 
with Confirmatory Factor Analysis/Outer Model which aim is to examine the relationship between unobserved latent variables that cannot be measured directly. This test is seen in terms of reliability and validity. Reliability is seen with composite reliability and alpha cronbach. While constructed validity was analyzed in two components; convergent validity (loading factor and AVE) and discriminant validity (AVE root and correlation between latent variables). Structural model testing is used to test hypothetical relationships or paths between latent variables. Structural models are seen from three standards; First is a measurement of the Determination Coefficient (R-Square) for each endogenous latent variable in a structural model with substantial criteria $(0.75)$, moderate $(0.50)$, and weak $(0,25)$; Second is a measurement of predictive relevance or Q (Squared); Third is the Size of Effect (F-Squared effect size) absolute value of individual contributions for each predictor latent variable in the variable R-Squared value criterion. Effect Size can be grouped into three categories; weak (0.02), medium (0.15), and large (0.35). Hypothesis testing is based on the level of significance and coefficient value. The hypothesis is accepted if the significance value is $<5 \%(0.05)$ and the coefficient value is in accordance with the direction of the hypothesis. On the contrary, if the significance value is $>5 \%(0.05)$ and the coefficient value is not appropriate, the hypothesis is not accepted (Ghozali 2002; Susanti 2010).

\section{Results and Discussion}

\section{Confirmatory Factor Analysis}

Each instrument used to measure research variables must have good reliability, where the composite value is $>0.70$. This is because reliability describes that the instrument used to measure the variables in this study consistently raises the same results every time a measurement is made. In addition, all research variables must also have discriminant validity values $>0.50 \mathrm{ob}-$ 
THE ROLE OF SPIRITUALITY IN THE BEHAVIOR ...

tained from comparing the square root value of average variance extracted for each variable with a correlation between other variables in the model. This is to show that the research instrument has good convergent validity. Because the instrument that has met the elements of convergent validity means that the instrument is able to collect data with the same pattern to measure the same construct. The values of composite reliability, loading factor, and average variance extracted (AVE) in this study can be seen in table 1.

\section{Table 1}

Reliability and convergent validity

\begin{tabular}{lc}
\hline \multicolumn{1}{c}{ Latent variable } & Loading \\
\hline KMD (Composite reliability $=0,851 ; A V E=0,588)$ & \\
KMD1 & $(0,807)$ \\
KMD2 & $(0,765)$ \\
KMD3 & $(0,719)$ \\
KMD4 & $(0,775)$ \\
\hline KMF (Composite reliability $=0,844 ; A V E=0,576)$ & \\
KMF1 & $(0,786)$ \\
KMF2 & $(0,769)$ \\
KMF3 & $(0,657)$ \\
KMF4 & $(0,815)$ \\
\hline SKP (Composite reliability $=0,835 ; A V E=0,559)$ & \\
SKP1 & $(0,718)$ \\
SKP2 & $(0,750)$ \\
SKP3 & $(0,816)$ \\
SKP4 & $(0,703)$ \\
\hline MNT (Composite reliability $=0,765 ; A V E=0,452)$ & \\
MNT1 & $(0,678)$ \\
MNT2 & $(0,602)$ \\
MNT3 & $(0,598)$ \\
MNT4 & $(0,793)$ \\
\hline PGN (Composite reliability $=0,771 ; A V E=0,459)$ & \\
PGN1 & $(0,683)$ \\
PGN2 & $(0,760)$ \\
PGN3 & $(0,613)$ \\
PNG4 & $(0,644)$ \\
\hline
\end{tabular}


SPT (Composite reliability $=0,788 ; A V E=0,650)$

SPT1

SPT2

Based on the table 1, the data show that all research variables have composite reliability values $>0.70$ and the indications of fulfilling discriminant validity in research instruments can be seen from the results of average variance extracted (AVE) root values $>$ other construct correlations. The AVE root results in the diagonal column must show that all variables have AVE roots higher than other construct correlations. The fulfillment of discriminant validity criteria in the research instrument can be known through the cross loading value < loading construct value. To find out whether the discriminant validity is fulfilled in this research instrument, it can be seen in table 2 .

Table 2

Discriminant validity

\begin{tabular}{ccccccc}
\hline & KMD & KMF & SKP & MNT & SPT & PGN \\
\hline KMD & $(0,767)$ & 0,556 & 0,664 & 0,569 & 0,337 & 0,469 \\
\hline KMF & 0,556 & $(0,759)$ & 0,671 & 0,572 & 0,537 & 0,336 \\
\hline SKP & 0,664 & 0,671 & $(0,748)$ & 0,640 & 0,449 & 0,429 \\
\hline MNT & 0,573 & 0,554 & 0,598 & $(0,672)$ & 0,513 & 0,302 \\
SPT & 0,337 & 0,537 & 0,449 & 0,513 & $(0,806)$ & 0,547 \\
\hline PGN & 0,589 & 0,598 & 0,655 & 0,655 & 0,547 & $(0,677)$ \\
\hline
\end{tabular}

Based on the data in table 2, it shows that the cross loading value < loading construct value, which is indicated by the average variance extracted (AVE) root value $>$ other construct correlation. So it can be concluded that the discriminant validity of the instrument in this study is fulfilled because it has a value $>0.50$.

\section{Structural Model Analysis}

Structural model analysis is used to test hypotheses and model fit. In this study, the hypotheses test and fit data model 
THE ROLE OF SPIRITUALITY IN THE BEHAVIOR ...

were carried out using WarpPLS 5.0 software. The results of full measurement of structural equation models can be seen in Figure 3.

Figure 3

Full model results

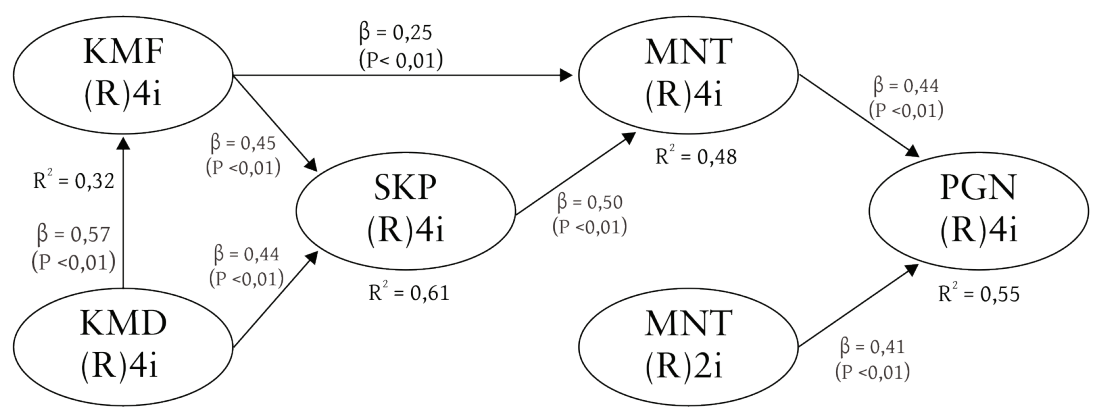

Figure 3 shows that all paths in the empirical research model show results that are significant at levels $<0.01$ and $<0.05$. To find out the model built whether it meets the criteria of the model that is fit or not, several indicators were used in the WarpPLS 5.0 software.

Some model fit indicators such as average path coefficient (APC), average R-squared (ARS), and average block VIF (AVIF) in this study can be seen in table 3 .

Table 3

Model fit

\begin{tabular}{llll}
\hline \multicolumn{1}{c}{ Indicator } & \multicolumn{1}{c}{ Value } & \multicolumn{1}{c}{ Standard } & Conclusion \\
\hline $\begin{array}{l}\text { Average path coefficient } \\
\text { (APC) }\end{array}$ & $0,439 \mathrm{P}<0,001$ & $\mathrm{P}<0,05$ & Model Fit \\
\hline Average R-squared (ARS) & $0,493 \mathrm{P}<0,001$ & $\mathrm{P}<0,05$ & Model Fit \\
\hline $\begin{array}{l}\text { Average adjusted } \\
\text { R-squared (AARS) }\end{array}$ & $0,484 \mathrm{P}<0,001$ & $\mathrm{P}<0,05$ & Model Fit \\
\hline Average block VIF (AVIF) & 1,498 & $\begin{array}{l}\text { acceptable if }<=5, \\
\text { ideally }<=3,3\end{array}$ & Model Fit \\
\hline $\begin{array}{l}\text { Average full collinearity } \\
\text { VIF (AFVIF) }\end{array}$ & 2,261 & $\begin{array}{l}\text { acceptable if }<=5, \\
\text { ideally }<=3,3\end{array}$ & Model Fit \\
\hline
\end{tabular}


The data in table 3 show that the criteria for the goodness of fit model have been fulfille where the APC value of 0.439 and ARS of 0.493 are all significant. The AVIF value as a multicollinearity indicator is 1.498 (smaller than 5) that meets the criteria. The full collinearity value of VIF which is the result of full collinearity testing that includes vertical and lateral multicollinearity shows a number of 2.261 (smaller than 3.3). This result shows that there are no linearity problems (relationships) either vertically or laterally. Vertical collinearity is the relationship between predictor variables, while lateral collinearity is the relationship between predictor variables and criteria.

\section{Discussion}

The first hypothesis a, which states that the perception of convenience has a positive effect on the attitude of mobile banking use, is accepted. These results are in accordance with the output of structural equation models in Figure 3 which shows that the coefficient value of the relationship between perceived ease (KMD) and the attitude of mobile banking use (SKP) is 0.44 and the $\mathrm{P}$ value is $<0.01$. Evidently the first hypothesis a answers the research question that asks whether ease of perception affects the attitude of using mobile banking. Because the results of empirical testing show that the perception of ease hypothesis has a positive effect on the use of mobile banking. This indicates that the ease of using mobile banking applications is able to influence the attitude of Islamic bank customers while using mobile banking applications. This is in line with the research conducted by (Larsson and Viitaoja 2017) that digital banking provides convenience for loyal customers.

The first hypothesis b, which states that the perception of convenience has a positive effect on the attitude of mobile banking use through the perception of use, is accepted. These results are in accordance with the output of structural equation models 
in Figure 3 which shows that the coefficient value of the relationship between perceived ease (KMD) and perceived usefulness $(\mathrm{KMF})$ is 0.57 and $\mathrm{P}$ value $<0.01$ and perceived usefulness with the attitude of using mobile banking (SKP) of 0.45 and $\mathrm{P}$ value $<0.01$. So that the KMD path coefficient value against SKP indirectly through KMF is 0.26 with a value of $\mathrm{p}<0.01$ obtained from $0.57 \times 0.45=0.26$. It is proven that the first hypothesis $b$ answers research questions that ask whether perceptions of ease have an effect on the attitude of using mobile banking through perceptions of usefulness. Because the results of empirical testing show that the perception of ease hypothesis has a positive effect on the attitude of using mobile banking through the perception of usefulness. The results of this study are consistent with the research conducted by (Mathuva, Mboya, and McFie 2017), which states that indirectly perceived ease of use has an influence on the attitude towards use through the customer's usefulness in Surabaya using mobile banking. This indicates that the ease in using the mobile banking application is able to influence the attitude of sharia bank customers while using the mobile banking application. (Peevers et al. 2011) in their research on sms banking which is part of mobile banking, it made customers easier to do transactio. Perceived usefulness has a positive effect on the attitude of using mobile banking.

The second hypothesis, which states that the perception of benefits has a positive effect on the attitude of mobile banking use, is accepted. This result is in accordance with the output of the structural equation model in Figure 3 which shows that the coefficient value of the relationship between perceived usefulness (KMF) and the attitude of using mobile banking (SKP) is 0.45 and the $\mathrm{P}$ value is $<0.01$. Evidently, the second hypothesis answers the research question that asks whether the perception of benefits affects the attitude of using mobile banking. Because 
the results of empirical testing show that the hypothesis of benefit perception has a positive effect on the attitude of using mobile banking. The results of this study are consistent with the research conducted by (Mathuva, Mboya, and McFie 2017), which states that the perceived usefulness has a positive effect on the attitude towards use of the customers in Surabaya who use mobile banking. This indicates that the benefits obtained by sharia bank customers from the use of mobile banking applications are able to influence the attitude of sharia bank customers while using mobile banking applications. (Narteh 2013) examines that one of the factors for companies to choose a bank is its facilities in the form of mobile banking.

The third hypothesis, which states that the attitude of use has a positive effect on the interest in the behavioral use of mobile banking, is also accepted. These results are in accordance with the output of the structural equation model in Figure 3 which shows that the coefficient value of the relationship between attitude of use (SKP) and interest in the behavior of mobile banking $(\mathrm{MNT})$ use is 0.50 and the value of $\mathrm{P}$ value is $<0.01$. Evidently, the third hypothesis answers the research question that asks whether the attitude of use influences the interest in the behavior of using mobile banking. Because the results of empirical testing show that the attitude of use has a positive effect on the interest in the behavioral use of mobile banking. The results of this study are consistent with the research conducted by Mathuva, Mboya, and McFie (2017) which states that attitude towards use has a positive influence on customers' behavioral intention in Surabaya that use mobile banking. Liu, Chen, and Chou (2011) state that banking transformation in the digital sector through mobile banking is a way to improve the customers' interest. This indicates that the attitude of sharia bank customers while using the mobile banking application is able to influence the interest of sharia bank customers to reuse the mobile banking application. 
The fourth hypothesis, which states that the benefit perception has a positive effect on the behavior interest of mobile banking use, is accepted. This result is in accordance with the output of the structural equation model in Figure 3 which shows that the coefficient value of the relationship between perceived usefulness $(\mathrm{KMF})$ and interest in behavioral use of mobile banking $(\mathrm{MNT})$ is 0.25 and the value of $\mathrm{P}$ value $=0.04(<0.05)$. Evidently, the fourth hypothesis answers the research question that asks whether the perception of expediency influences the behavior interest in using mobile banking. Because the results of empirical testing show that the benefit perception hypothesis has a positive effect on the interest in the behavior of using mobile banking. The results of this study are consistent with the research of (Akhtar 2013), which states that perceived usefulness has a positive and significant effect on the behavioral intention to use mobile banking. This indicates that the benefits obtained by sharia bank customers from the use of mobile banking applications are able to influence the interest of sharia bank customers to reuse the mobile banking application. But the customers certainly will consider two aspects; benefits and risks. (Dinger and Hagen 2009) research shows that internet banking increases banking risk.

The fifth hypothesis, which states that behavior interest has a positive effect on mobile banking use, is accepted. This result is in accordance with the output of the structural equation model in Figure 3 which shows that the coefficient value of the relationship between behavioral interest $(\mathrm{MNT})$ and the use of mobile banking (PGN) is 0.44 and the $\mathrm{P}$ value is $<0.01$. Evidently, the fifth hypothesis answers research questions that ask whether the interest in the behavior affects the use of mobile banking. Because the results of empirical testing show that the behavior interest hypothesis has a positive effect on the use of 
mobile banking. The results of this study are consistent with the research conducted by Rahmawaty (2012) and Danyali (2018), which states that behavior interest is positively related to the behavior of using internet banking products. This indicates that the use of mobile banking applications is first influenced by the interest of sharia bank customers to use the mobile banking application.

The sixth hypothesis, which states that spiritual motivation has a positive effect on mobile banking usae, is accepted. This result is in accordance with the output of the structural equation model in Figure 3 which shows that the path coefficient value of the relationship between spiritual motivation (SPT) and mobile banking (PNG) use is 0.44 and the $\mathrm{P}$ value is $<0.01$. It is proven that the sixth hypothesis answers research questions that ask whether spiritual motivation has a positive effect on the use of mobile banking. Because the results of empirical testing show that the spiritual motivation hypothesis has a positive effect on the use of mobile banking. The results of this study are consistent with the study conducted by (Rahmawaty 2012), which states that spiritual motivation is positively related to the interest in the behavior of receiving internet banking products. This indicates that the spiritual motivation of sharia bank customers is able to influence them to use the mobile banking application.

The results of the test of the first till sixth hypothesis can be summarized in the table 4 .

\section{Table 4}

Hypotheses testing results

\begin{tabular}{clc}
\hline Hypothesis & \multicolumn{1}{c}{ Description } & Result \\
\hline Hypothesis 1a & $\begin{array}{l}\text { Ease perception has a positive effect on the atti- } \\
\text { tude of using mobile banking. }\end{array}$ & Accepted \\
\hline Hypothesis 1b & $\begin{array}{l}\text { Ease perception has a positive effect on the atti- } \\
\text { tude of using mobile banking through the per- } \\
\text { ception of benefits. }\end{array}$ & Accepted \\
\hline
\end{tabular}


THE ROLE OF SPIRITUALITY IN THE BEHAVIOR ...

\begin{tabular}{cll}
\hline Hypothesis 2 & $\begin{array}{l}\text { Benefit perception has a positive effect on the } \\
\text { attitude of using mobile banking. }\end{array}$ & Accepted \\
\hline Hypothesis 3 & $\begin{array}{l}\text { The attitude of use has a positive effect on the } \\
\text { interest in the behavior of using mobile banking. }\end{array}$ & Accepted \\
\hline Hypothesis4 & $\begin{array}{l}\text { Benefit perception has a positive effect on inter- } \\
\text { est in the behavior of mobile banking usage. }\end{array}$ & Accepted \\
\hline Hypothesis5 & $\begin{array}{l}\text { Behavior intention has a positive effect on the } \\
\text { use of mobile banking. }\end{array}$ & Accepted \\
\hline Hypothesis 6 & $\begin{array}{l}\text { Spiritual motivation has a positive effect on the } \\
\text { use of mobile banking. }\end{array}$ & Accepted \\
\hline
\end{tabular}

\section{Conclusion}

To explain the behavior of mobile banking use in sharia bank, this study uses the Theory Acceptance Model with several variables; perceived ease, benefit perception, use attitude, behavioral interest, use and spiritual motivation. Based on the above analysis, this study provides empirical evidences that perception of ease has a positive effect on the attitude of using mobile banking, perceived ease positively influences the attitude of using mobile banking through perceived usefulness, perceived usefulness positively influences the attitude of using mobile banking, the attitude of use positively influences the interest in the behavioral use of mobile banking, perceived benefit positively influences the behavioral interest in using mobile banking, behavioral interest influences the use of mobile banking and spiritual motivation influences the use of mobile banking.

Based on the conclusions obtained in this study, it is expected that the sharia banking sector will continue to improve the quality of mobile banking services first, in order to be able to meet customer needs in conducting transactions in the banks. So that customers will continue to increase the use of mobile banking services. The second, the next researchers are expected to be able to expand the Theory Acceptance Model model to explain the behavior of use related to the problem being studied. And the third, for the people of this study, this researhch is 
expected to provide an understanding before making decision to choose and use sharia bank services that provide convenience and usefulness in accordance with the needs both materially and spiritually.

\section{Bibliography}

Agriyanto, Ratno. 2015. "Redefining Objective of Islamic Banking; Stakeholders Perspective in Indonesia." Economica 6 (2).

—. 2016. "Accrual Based AccountingImplementation: An Approach For Modelling Major Decisions.” Risk Governance \& Control 6 (12). doi:10.16309/j.cnki.issn.10071776.2003.03.004.

- 2017. "Model of Prediction of Behavioral Use of Accrual Basis Accounting Information on Local Government in Indonesia." Journal of Engineering and Applied Sciences 12 (33). doi:10.1108/17590811111170539.

Akhtar, Mohammad Hanif. 2013. "After the Financial Crisis: A Cost Efficiency Analysis of Banks from Saudi Arabia." International Journal of Islamic and Middle Eastern Finance and Management 6 (4): 322-32. doi:10.1108/ IMEFM-05-2013-0059.

Akturan, Ulun, and Nuray Tezcan. 2012. "Mobile Banking Adoption of the Youth Market: Perceptions and Intentions." Marketing Intelligence and Planning 30 (4): 44459. doi:10.1108/02634501211231928.

Alam, Syed Shah, Ali Khatibi, A. Solucis Santhapparaj, and Mohammad Talha. 2007. "Development and Prospects of Internet Banking in Bangladesh." Competitiveness Review 17 (1-2): 56-66. doi:10.1108/10595420710816614.

Alfani, Dennis Shabri. 2015. "Pengaruh Perceived Usefulness, Perceived Ease of Use, Perceived Credibility Dan Motivasi Spiritual Islam Pada Minat Nasabah Menggunakan Layanan Internet Banking Bank Syariah Mandiri Suraba- 
THE ROLE OF SPIRITUALITY IN THE BEHAVIOR ...

ya." Universitas Airlangga.

Anendro, Imam. 2016. "Analisis Faktor-Faktor Yang Mempengaruhi Minat Nasabah Bank Syariah Mandiri Terhadap Penggunaan E-Money.” UIN Sunan Kalijaga.

Bapat, Dhananjay. 2017. "Exploring the Antecedents of Loyalty in the Context of Multi-Channel Banking." International Journal of Bank Marketing 35 (2): 174-86. doi:10.1108/ IJBM-10-2015-0155.

Basias, Nikolaos, Marinos Themistocleous, and Vicenzo Morabito. 2013. "SOA Adoption in E-Banking." Journal of Enterprise Information Management 26 (6): 719-39. doi:10.1108/JEIM-07-2013-0042.

Danyali, Arezo Ahmadi. 2018. "Factors Influencing Customers' Change of Behaviors from Online Banking to Mobile Banking in Tejarat Bank, Iran.” Journal of Organizational Change Management 31 (6): 1226-33. doi:10.1108/ JOCM-07-2017-0269.

Digabriele, James A. 2009. "Implications of Regulatory Prescriptions and Audit Standards on the Evolution of Forensic Accounting in the Audit Process." Journal of Applied Accounting Research 10 (2): 109-21. doi:10.1108/09675420910984673.

Dinger, Valeriya, and Jürgen Von Hagen. 2009. “Does Interbank Borrowing Reduce Bank Risk?" Journal of Money, Credit and Banking 41 (2-3): 491-506. doi:10.1111/j.15384616.2009.00217.x.

Ghozali, Imam. 2002. "Pengaruh Religiositas Terhadap Komitmen Organisasi, Keterlibatan Kerja, Kepuasan Kerja Dan Produktivitas." Jurnal Bisnis Strategi 9.

Hans, Liang. 2014. "Bricks vs Clicks: Entrepreneurial Online Banking Behaviour and Relationship Banking." International Journal of Entrepreneurial Behaviour \&. Research 14 (1): 47-60.

Khakim, Abdul. 2016. "Pengaruh Persepsi Kemudahan, Persepsi Kemanfaatan, Dan Kelompok Referensi Terhadap Penggu- 
naan Alat Pembayaran Menggunakan Kartu APMK.” Thesis. IAIN Salatiga.

Kwateng, Kwame Owusu, Osei Atiemo, Kenneth Afo, and Charity Appiah. 2018. "Acceptance and Use of Mobile Banking: An Application of UTAUT2." Journal of Enterprise Information Management. doi:10.1108/JEIM-03-2018-0055.

Larsson, Anthony, and Yamit Viitaoja. 2017. "Building Customer Loyalty in Digital Banking: A Study of Bank Staff's Perspectives on the Challenges of Digital CRM and Loyalty." International Journal of Bank Marketing 35 (6): 858-77. doi:10.1108/IJBM-08-2016-0112.

Liu, Day Yang, Shou Wei Chen, and Tzu Chuan Chou. 2011. "Resource Fit in Digital Transformation: Lessons Learned from the CBC Bank Global e-Banking Project." Management Decision 49 (10): 1728-42. doi:10.1108/00251741111183852.

Mathuva, David M., Josephat K. Mboya, and James B. McFie. 2017. "Achieving Legitimacy through Co-Operative Governance and Social and Environmental Disclosure by Credit Unions in a Developing Country." Journal of Applied Accounting Research 18 (2): 162-84. doi:10.1108/ JAAR-12-2014-0128.

Minjoon, Joon. 2016. "Examining the Key Dimensions of Mobile Banking Service Quality: An Exploratory." International Journal of Bank Marketing 34 (2): 1-21.

Mullan, Jennifer, Laura Bradley, and Sharon Loane. 2017. "Bank Adoption of Mobile Banking: Stakeholder Perspective." International Journal of Bank Marketing 35 (7): 1152-72. doi:10.1108/IJBM-09-2015-0145.

Mutia, Islamylia dan Evi. 2016. "Pengaruh Sikap, Norma Subjektif, Kontrol Perilaku, Motivasi Spiritual Terhadap Minat Mahasiswa Akuntansi Dalam Memilih Konsentrasi Akuntansi Syariah Di Fakultas Ekonomi Universitas Syiah Kuala." Ilmiah Mahasiswa Ekonomi Akuntansi 1 (1): 193. doi:10.1360/zd-2013-43-6-1064. 
THE ROLE OF SPIRITUALITY IN THE BEHAVIOR ...

Narteh, Bedman. 2013. "SME Bank Selection and Patronage Behaviour in the Ghanaian Banking Industry." Management Research Review 36 (11): 1061-80. doi:10.1108/MRR06-2012-0147.

Peevers, G., G. Douglas, D. Marshall, and M. A. Jack. 2011. “On the Role of SMS for Transaction Confirmation with IVR Telephone Banking." International Journal of Bank Marketing 29 (3): 206-23. doi:10.1108/02652321111117494.

Poon, Wai Ching. 2008. "Users' Adoption of e-Banking Services: The Malaysian Perspective." Journal of Business and Industrial Marketing 23 (1): 59-69. doi:10.1108/08858620810841498.

Rahmawaty, Anita. 2012. "Model Perilaku Penerimaan Internet Banking Di Bank Syariah: Peran Motivasi Spiritual.” In Annual International Conference on Islamic Studies (AICIS) XII. Surabaya: MoRA.

Ratnaningrum, Luh Putu Rara Ayu. 2013. “Aplikasi Model TAM Terhadap Pengguna Layanan Internet Banking Di Kota Denpasar." Universitas Udayana 7 (1): 21.

Sa'diyah, Mahmudatus, and Nur Aziroh. 2013. "Mempengaruhi Tingkat Kepercayaan Nasabah Muslim Pengguna Mobile Banking Di Bank Muamalat Indonesia.” Equilibrium 1 (1). Sahilatua, Priska Febriani, and Naniek Noviari. 2013. "Penerapan Perencanaan Pajak Penghasilan Pasal 21 Sebagai Strategi Penghematan Pembayaran Pajak." E-Jurnal Akuntansi Universitas Udayana 5.1 (2013): 231-250 PENERAPAN 1: 231-50. doi:10.1109/PROC.1969.7161.

Saputri, Ainun Fika Budi Aji. 2015. "Pengaruh Keamanan, Kemudahan, Dan Risiko Kinerja Terhadap Keputusan Pembelian Secara Online." Jurnal Manajemen Bisnis Indonesia 4 (III).

Sharing Vision. 2015. "Pertumbuhan SMS/Mobile Banking Di Indonesia." Sharingvision.Com. https://sharingvision.com/ pertumbuhan-smsmobile-banking-di-indonesia/.

Shofwa, Yoiz. 2013. "Pengaruh Motivasi Spiritual Dan Kepemi- 
mpinan Spiritual Terhadap Kinerja Religius Dosen Dan Karyawan STAIN Purwokerto." Jurnal Pro Bisnis 6 (1): $1-19$.

Singh, Anesh Maniraj. 2004. "Trends in South African Internet Banking." Aslib Proceedings 56 (3): 187-96. doi:10.1108/00012530410539368.

Siradj, Said Aqil. 2017. "Ekonomi Syariah Teori Dan Terapan.” Sambutan Ketua Umum Pengurus Besar Nahdlatul Ulama (PBNU).

Suharyat, Yayat. 2009. "Hubungan Sikap, Minat Dan Perilaku Manusia." Jurnal FKIP 1 (3).

Susanti, Meilina Nur Indah. 2010. Statistik Deskriptif Dan Induktif. Yogyakarta: Graha Ilmu.

Tempo. 2016. "Pengguna Mobile Banking Di Indonesia Masih Rendah.” Tempo.Co. https://bisnis.tempo.co/read/811653/ pengguna-mobile-banking-di-indonesia-masih-rendah.

Wahyudi, Imam. 2014. "Commitment and Trust in Achieving Financial Goals of Strategic Alliance: Case in Islamic Microfinance." International Journal of Islamic and Middle Eastern Finance and Management 7 (4): 421-42. doi:10.1108/ IMEFM-10-2013-0113.

Warno. 2013. "Pengaruh Struktural Modal Terhadap Kepatuhan Membuat Laporan Keuangan Sesuai Standar Akuntansi Keuangan (SAK)." Jurnal Dinamika Ekonomi \& Bisnis 10 (1). doi:10.1080/02699930600684922.

—. 2014. "Kepatuhan Koperasi Di Kota Semarang Terhadap Standar Akuntansi Keuangan Entitas Tanpa Akuntan Publik (SAK ETAP) Tahun 2013.” Economica: Jurnal Ekonomi Islam 5 (1).

Yasa, I Wayan Catra. 2013. "Motivasi Spiritual, Budaya Kerja Dan Etos Kerja Sebagai Prediktor Terhadap Kepuasan Pedagang Melalui Kualitas Layanan Pedagang Kaki Lima Di Pasar Badung Bali." Universitas Terbuka, 17. doi:10.1108/17515631311325097. 